\title{
MENINGKATKAN KREATIVITAS DALAM MELUKIS PADA ANAK MELALUI KEGIATAN CANDLE MAGIC PAINTING
}

\author{
Dini Gustini \\ Program StudiPendidikan Guru PendidikanAnakUsia Dini, DepartemenPedagogik, \\ FakultasIlmuPendidikan, UniversitasPendidikan Indonesia
}

gustini.dini@yahoo.co.id

Rudiyanto dan Rita Mariyana

\begin{abstract}
Improving Creativity in Painting Children Through Candle Magic Painting Activity. This study aims to find out the description of how to improve creativity in painting children through candle magic painting activities, knowing the objective conditions before and after held research Method used in this research is the Classroom Action research method and collaborate with classroom teachers. This research was conducted on the children of group B in Muslimat Baiturrohmah Kindergarten District Astanaanyar Bandung, with the number of research subjects as many as 15 children aged 5-6 years. The research data was obtained by using research instrument in the form of guidance of children creativity observation. This research is done by four stages, they are planning stage, implementation stage, observation stage, and reflection. This research uses two cycles that are Cycle I and Cycle II in each cycle consist of 2 actions. Initial condition of creativity ability of children in painting in group B Muslimat Baiturrohmah Kindergarten still not developed optimally, with percentage category less $(K) 45.83 \%$, enough category $(C) 47.5 \%$, and good category $(B) 6.67 \%$. namu after given painting activity through candle magic painting activity creativity ability in painting children have significant improvement. The percentage of creativity ability in painting children with less category $(K)$ to $2.5 \%$, enough category $(C) 25 \%$, and good category $(B) 72.5 \%$.
\end{abstract}

Keywords: child creativity, painting, candle magic painting activities

\begin{abstract}
Abstrak: Meningkatkan Kreativitas dalam Melukis pada Anak Melalui Kegiatan Candle Magic Painting. Penelitian ini bertujuan untuk mengetahui mengetahui gambaran mengenai bagaimana peningkatan kreativitas dalam melukis anak melalui kegiatan candle magic painting, mengetahui kondisi objektif sebelum dan sesudah diadakan penelitianMetode yang digunakan dalam penelitian ini adalah metode Penelitian Tindakan Kelas dan melakukan kolaborasi dengan guru kelas. Penelitian ini dilakukan pada anak kelompok B di TK Muslimat Baiturrohmah Kecamatan Astanaanyar Bandung, dengan jumlah subjek penelitian sebanyak 15 orang anak yang berusia 5-6 tahun. Data penelitian diperoleh dengan menggunakan instrumen penelitian berupa pedoman observasi kreativitas anak. Penelitian ini dilakukan dengan empat tahap yaitu tahap perencanaan, tahap pelaksanaan, tahap observasi, dan refleksi. Penelitian ini menggunakan dua siklus yaitu Siklus I dan Siklus II pada setiap siklusnya terdiri dari 2 tindakan. Kondisi awal kemampuan kreativitas anak dalam melukis di kelompok B TK Muslimat Baiturrohmah masih belum berkembang secara optimal, dengan persentase kategori kurang (K) 45.83\%, kategori cukup (C) 47.5\%, dan kategori baik (B) 6.67\%. namu setelah diberikan kegiatan melukis melalui kegiatan candle magic painting kemampuan kreativitas dalam melukis anak mengalami peningkatan yang signifikan. Presentase kemampuan kreativitas dalam melukis anak dengan kategori kurang (K) menjadi 2.5\%, kategori cukup (C) 25\%, dan kategori baik (B) $72.5 \%$.
\end{abstract}

Kata Kunci: kreativitas anak, melukis, kegiatan candle magic painting 


\section{PENDAHULUAN}

Manusia pada dasarnya memiliki pengetahuan, keterampilan, dan nilai estetika agar dapat hidup dengan baik di masyarakat dan memiliki rasa keindahan. Sudah sejak dilahirkan ke dunia seorang manusia telah membawa kemampuan untuk berpikir. Pikiran adalah bagian dari otak, bagian yang digunakan yaitu untuk pemahaman, penalaran, pengetahuan dan pengertian. Pikiran anak telah aktif sejak anak tersebut lahir dan akan terus berproses sepanjang pertumbuhannya. Perkembangan pemikiran atau kognitif anak tidak dapat berjalan sendiri tapi membutuhkan pengarahan dan pembelajaran dari orang yang lebih dewasa. Diantaranya didapat dari penjelasan guru.

Selain belajar dengan guru anak dapat memanfaatkan alat peraga dan media sebagai sumber belajar. Namun tidak semua PAUD mempunyai media dan alat peraga yang dapat digunakan tiap kegiatan belajar mengajar hal ini dikarenakan adanya perbedaan tingkat kemampuan keuangan di masing-masing pendidikan anak usia dini. Di sinilah guru diminta untuk lebih kreatif dan terampil memanfaatkan berbagai barang dan benda yang ada di sekitar lingkungan menjadi sumber belajar yang menarik bagi anak.

Tujuan pendidikan pada umumnya adalah menyediakan lingkungan yang memungkinkan peserta didik untuk mengembangkan bakat dan kemampuan yang dimilikinya secara optimal. Setiap anak memiliki bakat dan kemampuan yang berbeda-beda sehingga memerlukan pendidikan yang berbeda pula. Dulu orang menentukan bakat seseorang ditentukan dari tingkat kecerdasan (IQ) yang dimiliki, namun sekarang bakat tidak hanya ditentukan oleh kecerdasan saja melainkan ditentukan oleh kreativitas dan motivasi untuk berprestasi.

Adapun yang menjadi tujuan program kegiatan PAUD mencangkup bidang pengembangan membentuk perilaku dan bidang pengembangan kemampuan dasar melalui kegiatan bermain dan pembiasaan. Lingkungan pengembangan meliputi: (1) nilai-nilai agama dan moral, (2) fisik, (3) kognitif, (4) bahasa, (5) sosial emosional. Kegiatan pengembangan suatu aspek dilakukan secara terpadu dengan aspek yang lain, menggunakan pendekatan tematik (Permendiknas no. 58 tahun 2009).

Sebagai pendidik guru memiliki kewajiban untuk memfasilitasi semua aspek perkembangan anak usia dini agar anak mencapai kematangan dengan baik dan mampu menyeimbangkan antara stimulus terhadap otak kanan dan otak kiri. Salah satunya yaitu meningkatkan aspek perkembangan kreativitas anak. Anak yang pintar itu bukan hanya dilihat dari akademiknya saja, melainkan kreativitas yang tinggi dan rasa ingin tahunya yang tinggi.

Meskipun kreativitas begitu penting bagi setiap manusia, namun pada kenyataannya ada banyak masalah yang terjadi dalam pengembangan kreativitas tersebut. Supriadi (dalam Rachmawati dan Kurniati, 2010: 9) menyatakan bahwa akar permasalahan dalam pengembangan kreativitas adalah sistem pendidikan saat ini yang berorientasi pada pendekatan "akademik" yang lebih berupaya membentuk manusia untuk menjadi "pintar di sekolah saja" dan "tuntutan dari orangtua yang ingin anaknya pintar dalam calistung" bukan menjadi manusia seutuhnya yang kreatif.

Santrock 2002 (Yulianti, 2010:

38) berpendapat bahwa kreativitas adalah kemampuan untuk memikirkan sesuatu dengan cara-cara yang baru 
dan tidak biasa serta melahirkan suatu solusi yang unik terhadap masalahmasalah yang dihadapi.

Kesadaran akan kreativitas pada saat ini sangatlah tinggi. Oleh sebab itu pendidikan mengemban tugas untuk dapat mengembangkan potensi kreatif yang dimiliki setiap setiap anak. Anak perlu mendapat bimbingan yang tepat, sehingga memungkinkan mereka untuk dapat mengembangkan potensi dan kemampuan secara optimal. Pada akhirnya kemampuan tersebut diharapkan dapat berguna baik bagi dirinya, keluarga maupun masyarakat luas pada umumnya.

Kreativitas mempunyai peranan yang sangat penting bagi kehidupan anak. Melalui kreativitas, anak dapat berkreasi sesuai dengan bakat ataupun kemampuan, anak dapat memecahkan suatu masalah dan dapat meningkatkan kualitas hidupnya di masa yang akan datang.

Adapun pengertian melukis menurut Marjono dan Suyatno (1990: 21) melukis adalah suatu kegiatan manusia dalam proses menggambar. Melukis hakikatnya adalah menggambar, hanya perbedaannya apabila melukis sangat mengutamakan perasaan yang dibentuk menjadi lukisan. Pencampuran daripada ide-ide atau daya cipta perasaan dan pikiran seseorang diwujudkan melalui bentuk gambar garis, bidang dicampur dengan warna sehingga menghasilkan bentuk lukisan yang indah dan menarik.

Candle magic painting adalah salah satu teknik melukis yang menyenangkan untuk anak usia dini dimana alat yang digunakan adalah lilin. Hal yang menjadi daya tarik bagi anak adalah magic yang dihasilkan oleh lilin, gambar yang proses awalnya tidak terlihat oleh anak akan terlihat apabila hasil gambaran yang telah dibuat di lukis oleh cat poster dan dikeringkan dengan sinar matahari.

Melihat dari sisi sistem pendidikan yang ada di Taman Kanakkanak, kebanyakan sistem pendidikan yang tidak mendorong berkembangnya kreativitas anak adalah guru tidak memberikan kesempatan kepada anak untuk menuangkan ide-ide mereka, bereksplorasi, percaya diri serta menghargai hasil karya orang lain, dan juga kurangnya fasilitas yang ada baik itu sumber daya manusia ataupun faktor lainnya. Dengan sisitem pendidikan seperti itu yang dilakukan secara terusmenerus, maka akan membuat anak kurang muncul potensi kreatifnya dikarenakan terbiasa dengan sistem pendidikan yang monoton.

Berdasarkan deskripsi tersebut betapa pentingnya Pendidikan Anak Usia Dini dan memiliki kontribusi yang sangat tinggi untuk perkembangan anak selanjutnya, selain itu jika otak anak mendapatkan rangsangan dan stimulus yang baik dari lingkungannya maka akan berkembang baik bagi pertumbuhan dan perkembangan anak, begitu pula sebaliknya.

Pentingnya kreativitas bagi anak, karena kreativitas merupakan bagian dari suatu gagasan individu untuk melahirkan gagasan dan produk baru. Sayangnya kreativitas kurang dikembangkan sejak dini, terutama pada Taman Kanak-Kanak yang memiliki fasilitas yang terbatas. Salah satu kreativitas yang akan dikembangkan yaitu kreativitas melukis dengan kegiatan candle magic painting.

Berdasarkan latar belakang masalah yang di uraikan di atas, maka rumusan masalah dalam penelitian ini adalah sebagai berikut :

1. Bagaimana kondisi objektif kreativitas anak pada kelompok B di TK Muslimat Baiturrohmah Bandung? 
2. Bagaimana kegiatan dalam melukis anak melalui kegiatan candle magic painting untuk meningkatkan kreativitas anak kelompok B di TK Muslimat Baiturrohmah Bandung?

3. Bagaimanakah peningkatan kreativitas dalam melukis anak setelah kegiatan candle magic painting pada anak kelompok B di TK Muslimat Baiturrohmah Bandung?

Adapun tujuan yang ingin dicapai dalam penelitian ini adalah tujuan umum dan tujuan khusus. Tujuan umum dari penelitian ini adalah untuk mengetahui gambaran mengenai bagaimana peningkatan kreativitas dalam melukis anak melalui kegiatan candle magic painting di TK Muslimat Baiturrohmah Kelompok B. Adapun tujuan khusus dalam penelitian ini adalah sebagai berikut:

a. Mendeskripsikan kondisi objektif kreativitas anak pada kelompok B di TK Muslimat Baiturrohmah Bandung.

b. Mendeskripsikan kegiatan dalam melukis anak melalui kegiatan candle magic painting untuk meningkatkan kreativitas anak kelompok B di TK Muslimat Baiturrohmah Bandung.

c. Mendeskripsikan peningkatan kreativitas dalam melukis anak setelah kegiatan candle magic painting pada anak kelompok B di TK Muslimat Baiturrohmah Bandung.

\section{METODE}

Metode penelitian yang digunakan adalah Metode Penelitian Tindakan Kelas (classroom action research) disingkat dengan PTK. Penelitian Tindakan Kelas adalah suatu kegiatan penelitian yang dilakukan di dalam kelas.
Adapun tujuan dari Penelitian Tindakan Kelas menurut Sukardi (2003: 212) dalam diantaranya:

1. Merupakan salah satu cara srategis guna memperbaiki layanan maupun hasil kerja suatu lembaga pendidikan.

2. Mengembangkan rencana tindakan kelas guna meningkatkan kinerja yang sekarang sedang dan telah dilakukan.

3. Mewujudkan proses penelitian yang bermanfaat ganda baik bagi peneliti maupun bagi lembaga pendidikan yang diteliti.

4. Tercapainya konteks pembelajaran dari pihak yang terlibat yaitu peneliti, para subjek yang diteliti serta guru dan tenaga kependidikan yang lainnya.

5. Timbulnya budaya meneliti yang memiliki nilai ganda yakni sambil bekerja sambil melakukan penelitian di bidang pekerjaan yang ditekuni.

6. Timbulnya perubahan pada subjek yang diteliti karena dampak dari tindakan yang dilakukan oleh peneliti sehingga bisa meningkatkan kualitass belajar siswa yang diteliti.

7. Diperolehnya pengalaman dan hasil penelitian yang selanjutnya dapat digunakan sebagai rujukan dalam rangka meningkatkan kualitas mengajar guru pada umumnya serta peeliti pada khususnya.

PTK ini dilaksanakan di TK Muslimat Baiturrohmah dengan subjek penelitian sebanyak 15 orang. Penelitian tindakan kelas ini dilaksanakan dalam dua siklus dimana setiap siklusnya dilakukan dua pertemuan. Instrumen penelitian yang dilakukan dalam penelitian adalah, observasi, wawancara, dan dokumentasi. Observasi dilakukan untuk melihat sejauh mana poses 
pembelajaran berlangsung dan melihat dampak dari kegiatan candle magic painting dalam meningkatkan kreativitas anak di Taman Kanak-kanak Muslimat Baiturrohmah. Observasi adalah suatu teknik yang dilakukan dengan cara mengadakan pengamatan secara teliti dan sistematis (Arikunto, 2006). Pengumpulan data melalui observasi di lakukan sendiri oleh peneliti dan berkolaborasi dengan guru kelas. Observasi yang dilakukan meliputi proses belajar mengajar guru dan anak dengan menggunakan kegiatan candle magic painting. Observasi dilakukan dengan menggunakan alat bantu kamera, pedoman observasi, catatan lapangan dengan tujuan membantu mengatasi halhal yang memungkinkan tidak teramati dan di dokumentasikan dengan baik dan rinci oleh peneliti. Teknik pengumpulan data selanjutnya adalah wawancara. Menurut Muslehudin (2009: 101) wawancara dapat dilakukan secara bebas atau terstruktur. Pedoman wawancara yang dilakukan oleh peneliti yaitu melakukan wawancara terstruktur. Hal ini dilakukan oleh peneliti agar dapat memperoleh informasi yang menyangkut dengan penelitian secara lengkap dan jelas. Pengumpulan data yang ketiga adalah dokumentasi. Studi dokumentasi dalam penelitian ini dilakukan untuk memperoleh data atau informasi selama proses pembelajaran berlangsung secara lebih jelas dan objektif serta data yang diperlukan. Dokumentasi yang dilakukan oleh peneliti dalam penelitian ini adalah berupa foto-foto terkait.

\section{HASIL DAN PEMBAHASAN}

Jadwal Pelaksanaan Tindakan pada
Setiap Siklus I dan II
\begin{tabular}{|c|c|c|c|}
\hline $\mathbf{N}$ & Hari/Tang & Pelaksana & $\begin{array}{c}\text { Wak } \\
\text { tu }\end{array}$ \\
\hline $\mathbf{o}$ & gal & an & \pm 120 \\
\hline 1. & Senin, 14 & Tema: & \pm 120 \\
\hline
\end{tabular}

\begin{tabular}{|c|c|c|c|}
\hline & $\begin{array}{l}\text { Agustus } \\
2017 \\
\text { Rabu, } 16 \\
\text { agustus } \\
2017\end{array}$ & $\begin{array}{l}\text { Tanah } \\
\text { Airku } \\
\text { Sub Tema: } \\
\text { Negaraku }\end{array}$ & menit \\
\hline 2. & $\begin{array}{l}\text { Senin, 28 } \\
\text { Agustus } \\
2017 \\
\text { Rabu, } 30 \\
\text { Agustus } \\
2017\end{array}$ & $\begin{array}{l}\text { Tema: } \\
\text { Lingkunga } \\
\text { nku } \\
\text { Sub Tema: } \\
\text { Rumahku }\end{array}$ & $\begin{array}{l} \pm 120 \\
\text { menit }\end{array}$ \\
\hline
\end{tabular}

Berikut peneliti mendeskripsikan hasil penelitian, yaitu perencanaan, pelaksanaan dan pengamatan, serta refleksi atau hasil belajar, sebagai berikut :

1. Siklus I

\section{a. Perencanaan}

Penerapan penelitian tindakan kelas sebagai upaya meningkatkan kreativitas dalam melukis anak kelompok B peneliti menerapkan kegiatan Candle Magic Painting, peneliti membuat perencanaan yang dituangkan di dalam Rencana Pelaksanaan Pembelajaran Harian (RPPH), menyiapkan media dan sumber pembelajaran yang akan digunakan, pengelolaan kelas, menyiapkan lembar kerja siswa dan alat bahan pendukung kegiatan pembelajaran. Membuat pedoman observasi dan catatan lapangan serta dokumentasi untuk memudahkan peneliti memperoleh data.

b. Pelaksanaan Tindakan

Pada pelaksanaan pertama siklus I, penerapan kegiatan candle magic painting guru sesuai dengan perencanaan yang telah dibuat dalam rancangan pelaksanaan pembelajaran harian (RPPH), langkah-langkah pembelajaran, serta media yang akan digunakan dalam melakukan kegiatan pembelajaran. Pelaksanaan kegiatan tindakan dilakukan secara kolaboratif antara guru kelas dengan peneliti 
sebagai observer. Pelaksanaan siklus I yang dilakukan pada hari Senin dan Rabu, tanggal 14 dan 16 Agustus 2017 dengan alokasi waktu \pm 120 menit.

Observasi atau pengamatan dilakukan oleh peneliti dari awal pelaksanaan pembelajaran hingga akhir kegiatan yang dilakukan oleh guru dan peneliti mengamati setiap kegiatan yang dilakukan anak dalam kegiatan pembelajaran sebagai upaya meningkatkan kreativitas dalam melukis anak.

c. Pengamatan

Selama proses kegiatan belajar mengajar berlangsung, peneliti melakukan observasi atau pengamatan pada proses pembelajaran yang dilakukan dengan berdasarkan pada indikator yang telah di tentukan.

\section{d. Refleksi}

Dari data observasi yang diperoleh pada tindakan 2 siklus I ini anak sudah mengalami peningkatan kreativitas dalam melukis melalui kegiatan candle magic painting yang dapat dilihat dari tabel 4.6 diatas dimana anak yang masih mendapatkan nilai kurang berkembang hanya terdapat 3 orang, sedangkan yang mendapatkan nilai cukup terdapat 5 orang anak, dan 7 orang anak sudah mengalami peningkatan kreativitas.

\section{Siklus II}

\section{a. Perencanaan}

Peneliti kembali merancang kegiatan candle magic painting yang akan diterapkan pada siklus II seperti menyusun Rencana Pelaksanaan Pembelajaran (RPPH), menyiapkan media yang akan digunakan dan menyiapkan lembar kerja siswa dan alat bahan pendukung kegiatan pembelajaran. b. Pelaksanaan Tindakan

Pelaksanaan kegiatan candle magic painting pada siklus II ini dilakukan pada hari Senin 28 Agustus 2017 yang dilakukan oleh guru dengan perencanaan yang telah dituangkan pada Rencana Pelaksanaan Pembelajaran Harian (RPPH). Pelaksanaan kegiatan tindakan dilakukan secara kolaboratif antara guru kelas dengan peneliti sebagai observer dengan alokasi waktu \pm 120 menit.

Peneliti mengikuti kegiatan dari awal sebelum masuk kelas hingga kegiatan belajar mengajar berakhir, pengamatan atau observasi dilakukan dari kegiatan dilakukan oleh guru dan berbagai hal yang terjadi dari anak melalui pedoman observasi dan catatan lapangan serta dokumentasi.

Pada penerapan kegiatan candle magic painting mulanya anak melihat video mengenai lingkungan di sekitar mulai dari lingkungan rumah, sekolah, dan lingkungan sekitarnya. Sebelum memulai kegiatan anak memakai celemek plastik agar saat anak melukis cat tidak terkena baju seragam Setelah itu anak diberikan alat dan bahan satu persatu secara tertib, mulai dari kertas tebal, lalu lilin untuk membentuk rumah dan bentuk lainnya, kemudian lilin disimpan di loker masing-masing dan anak kembali ke kursinya, mula-mula gambaran yang dibuat anak tidak terlihat lalu anak diberi cat dan kuas untuk memulasnya dengan warna yang di inginkan anak. Sentuhan terakhir ini menghasilkan magic yang membuat anak terkesan bahwa lukisan yang awalnya tidak terlihat menjadi terlihat dengan sentuhan kuas dan cat poster. Setelah anak selesai semuanya maka lukisan yang 
dibuat oleh anak bisa langsung dikeringkan/dijemur.

\section{c. Pengamatan}

Berdasarkan hasil obsrvasi atau pengamatan yang dilakukan peneliti selama pelaksanaan tindakan pada siklus II, sudah terlihat kreativitas dalam melukis anak sudah mulai berkembang dengan baik.

\section{d. Refleksi}

Dari data observasi yang diperoleh pada siklus II ini terlihat anak sudah mengalami peningkatan kreativitas dalam melukis melalui kegiatan candle magic painting yang signifikan hal ini dapat dilihat dari pencapaian masing-masing indikator pada siklus I yang dibandingkan dengan peningkatan kreativitas dalam melukis pada siklus II.

3. Peningkatan Hasil Belajar

Dari data yang telah di paparkan berdasarkan pengamatan atau hasil observasi dari lapangan peneliti menyimpulkan bahwa peneliti mengalami keberhasilan dalam upayameningkatkan kreativitas dalam melukis anak melalui kegiatan candle magic painting terlihat dari perkembangan anak pada sebelum diberikan tindakan (pra siklus) yaitu 6 orang anak mendapatkan nilai kurang (45.83\%), 8 orang anak mendapatkan nilai cukup (47.5\%) dan 1 orang anak mendapatkan nilai baik $(6.67 \%)$. Setelah itu juga terlihat pada siklus I, 3 orang anak yang mendapatkan nilai kurang sebanyak (14.17\%), 5 orang anak mendapatkan nilai cukup $(50.83 \%)$, dan 7 orang anak mendapatkan nilai terbaik (35\%). Jika data tersebut disajikan dalam bentuk grafik, yaitu sebagai berikut :

\section{Peningkatan Kreativitas dalam Melukis Anak Kelompok B TK Muslimat Baiturrohmah}

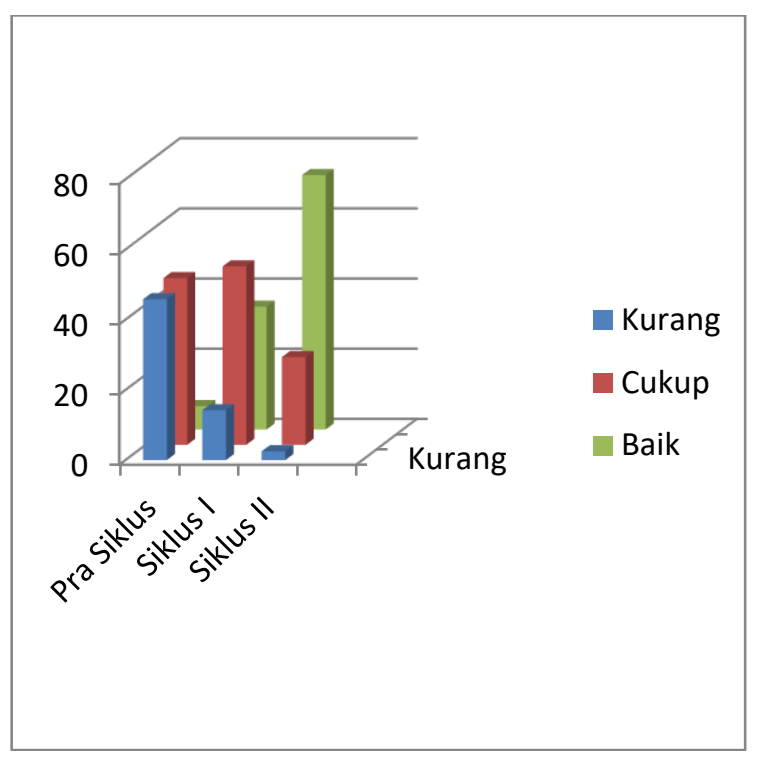

\section{B. Pembahasan}

Dalam pembahasan ini akan memaparkan hasil dari penelitian yang telah dilaksanakan, dan akan melengkapi penjelasan yang sebelumnya.

\section{Kondisi Objektif Kemampuan Kreativitas dalam Melukis Anak Kelompok B di TK Muslimat Baiturrohmah sebelum Diterapkan Kegiatan Candle Magic Painting}

Kemampuan kreativitas anak Kelompok B TK Muslimat Baiturrohmah sebelum diterapkan kegiatan candle magic painting dikatakan belum berkembang secara optimal berdasarkan prasiklus 8 indikator yang diteliti menunjukan bahwa 6 orang anak mendapatkan nilai kurang (45.83\%), 8 orang anak mendapatkan nilai cukup (47.5\%) dan 1 orang anak mendapatkan nilai baik $(6.67 \%)$. Kemampuan kreativitas dalam melukis anak di TK Muslimat Baiturrohmah dikatakan belum berkembang secara optimal dilihat dari anak belum dapat melakukan kegiatan secara mandiri, seringkali sulit untuk menuangkan sebuah ide dan imajinasinya pada sebuah karya, anak seringkali meniru hasil dari 
temannya atau gurunya, anak tidak merasa percaya diri dengan kemampuannya sendiri dan seringkali mengeluh dan mengatakan "ibu aku gabisa".

\section{Penerapan Kegiatan Candle Magic Painting dalam Meningkatkan Kreativitas dalam Melukis Anak Kelompok B di TK Muslimat Baiturrohmah}

Kegiatan candle magic painting ini dipilih sebagai solusi untuk meningkatkan kreativitas dalam melukis anak karena dilakukan secara langsung, dimana anak dapat meluangkan ide-ide sesuai dengan imajinasi anak secara kreatif. Secara tidak langsung hal ini akan dapat meningkatkan kreativitas dalam melukis anak. Sebagaimana menurut Rachmawati \& Kurniati (52: 2010) mengungkapkan pengembangan kreativitas pada anak melalui kegiatan hasta karya memiliki posisi penting dalam berbagai aspek perkembangan anak.

a. Siklus I

Siklus I dilaksanakan pada tanggal 14 Agustus dan 16 Agustus 2017 dengan tema tanah airku dan subtema negaraku, kegiatan yang digunakan adalah candle magic painting sebagai kegiatan inti anak melukis dengan menggunakan lilin untuk membentuk subtema negaraku. Pada kegiatan ini anak sangat antusias mengikuti kegiatan ini karena kegiatan ini merupakan kegiatan pertama yang dilakukan selama ini karena kegiatan ini belum pernah dilakukan sebelumnya, terlihat dari terdapat beberapa anak yang tidak mau berhenti saat waktunya istirahat dan bahkan anak terus melanjutkan kegiatannya.

Peningkatan kreativitas dalam melukis anak secara keseluruhan yang belum berkembang secara optimal dalam kategori kurang mulai mengalami penurunan yaitu hanya mendapatkan nilai kurang $14.17 \%$, untuk kategori nilai cukup meningkat menjadi 50.83\%, dan untuk kategori baik meningkat menjadi $\quad 35 \%$. Peningkatan kreativitas dalam melukis ini menunjukan bahwa memang kegiatan candle magic painting yang terapkan pada dasarnya dapat meningkatkan kreativitas dalam melukis anak.

b. Siklus II

Siklus II dilaksanakan pada tanggal 28 Agustus dan 30 Agustus 2017 dengan tema lingkunganku dan subtema rumahku, kegiatan yang digunakan adalah candle magic painting sebagai kegiatan inti anak melukis dengan menggunakan lilin untuk membentuk subtema negaraku. Pada kegiatan ini anak sangat antusias mengikuti kegiatan ini karena kegiatan ini merupakan kegiatan pertama yang dilakukan selama ini karena kegiatan ini belum pernah dilakukan sebelumnya, terlihat dari beberapa anak yang tidak mau berhenti saat waktunya istirahat dan bahkan anak terus melanjutkan kegiatannya.

Peningkatan kreativitas dalam melukis anak pada siklus II ini secara keseluruhan yaitu untuk kategori nilai kurang menjadi $2.5 \%$, untuk kategori nilai cukup menjadi $25 \%$, dan untuk kategori baik menjadi $72.5 \%$. Peningkatan yang signifikan ini peneliti memutuskan untuk berhenti pada 
siklus II karena anak sudah mengalami peningkatan kreativitas dalam melukis anak $\geq 70 \%$. Artinya kegiatan candle magic painting ini memang salah satu solusi yang tepat untuk meningkatkan kreativitas dalam melukis anak. Pada dasarnya semua anak adalah kreatif, namun harus diberikan arahan dan bimbingan agar potensi kreatif tersebut dapat berkembang secara optimal.

\section{Peningkatan Kreativitas dalam Melukis Anak Melalui Kegiatan Candle Magic Painting Kelompok B di TK Muslimat Baiturrohmah}

melukis $\begin{array}{cr}\text { Kreativitas } & \text { dalam } \\ \text { anak } & \text { mengalami }\end{array}$ peningkatan secara terus menerus mulai dari siklus I sampai siklus II. Hal ini dapat dilihat dari perbandingan pada saat pra siklus yang belum menggunakan kegiatan candle magic painting dan pada saat siklus I dan siklus II yang sudah menggunakan kegiatan candle magic painting. Pada saat pra siklus kreativitas dalam kategori nilai kurang (K) sebanyak $45.83 \%$, dengan kategori nilai cukup (C) sebanyak 47.5\%, dan sebanyak $6.67 \%$ dengan kategori baik (B). Pada penerapan kegiatan siklus I perkembangan kreativitas dalam melukis anak sudah mulai berkembang dengan baik yaitu anak dengan kategori nilai kurang (K) mulai mengalami penurunan menjadi $14.17 \%$, sebanyak $50.83 \%$ anak yang mendapatkan kategori cukup (C), dan sebanyak $35 \%$ anak yang mendapat nilai baik (B). Penerapan kegiatan pada siklus II perkembangan kreativitas dalam melukis anak mengalami peningkatan yang signifikan di bandingkan dengan pra siklus dan juga siklus I. Peningkatan kreativitas pada siklus II ini yaitu sebanyak $2.5 \%$ dengan kriteria kurang (K), 25\% dengan kriteria cukup (C), dan sebanyak $72.5 \%$ dengan kriteria baik (B).

Peningkatan kreativitas dalam melukis anak melalui kegiatan candle magic painting ini dikatakan sudah mengalami peningkatan sesuai dengan yang diharapkan dilihat dari persentase yang di dapat dari hasil pengamatan (observasi) yang dalam setiap siklusnya meningkat. Terjadinya peningkatan tersebut dikarenakan kegiatan candle magic painting merupakan kegiatan yang sangat mendukung perkembangan kreativitas anak.

\section{KESIMPULAN}

Berdasarkan hasil penelitian tindakan kelas tentang "Meningkatkan Kreativitas dalam Melukis Anak Kelompok B di TK Muslimat Baiturrohmah", berdasarkan rumusan masalah yang ditentukan maka dapat disimpulkan sebagai berikut:

1. Kondisi objektif kreativitas dalam melukis anak Kelompok B TK Muslimat Baiturrohmah sebelum diterapkan kegiatan candle magic painting pada umumnya kreativitas anak belum berkembang secara optimal, terutama pada saat membuat karya yang masih meniru dari gurunya atau temannya, terkadang anak mengungkapkan "ibu aku gabisa" sebelum melakukan kegiatan, kurangnya kepercayaan diri anak seperti saat anak menjelaskan hasil karyanya.

2. Penerapan kegiatan candle magic painting untuk meningkatkan 
kreativitas dalam melukis anak Kelompok B TK Muslimat Baiturrohmah. Penelitian ini dilaksanakan dalam dua siklus. Dalam pelaksanaan pembelajaran melalui kegiatan candle magic painting dari siklus I sampai siklus II terlihat perkembangan kreativitas anak meningkat dan mencapai tujuan yang diharapkan. Keterlibatan dan motivasi anak dalam pembelajaran melalui kegiatan candle magic painting mengalami peningkatan, dimana anak lebih senang dan tertarik dalam membuat lukisan yang dibuatnya, anak tertarik saat memulai hasil lukisannya. Proses pembelajaran menggunakan kegiatan candle magic painting yang dilakukan melalui tahap perencanaan, pelaksanaan, pengamatan/observasi, dan refleksi.

3. Peningkatan kreativitas dalam melukis anak kelompok B di TK Muslimat Baiturrohmah setelah diterapkannya kegiatan candle magic painting mengalami peningkatan. Hal ini dapat terlihat dari hasil pencapaian indikator kreativitas anak yang sudah mampu menuangkan imajinasinya kedalam suatu lukisan, mampu membuat karya yang sesuai dengan ide/gagasan secara spontan tanpa meniru hasil karya orang lain, mampu menggunakan warna-warna yang sudah ditentukan, mampu melukis tanpa hambatan dan tidak banyak bertanya.

\section{DAFTAR PUSTAKA}

Arikunto, S. (2006). Prosedur penelitian. Jakarta: PT Rineka Putra.

Muslehudin. (2009). Kiat Sukses Melakukan Tindakan Kelas. Bandung: Rizqi Press.

Marjono, D., dan Suyatno. (1990). Pendidikan Seni Rupa. Bandung: Ganeca Exact.

Peraturan Menteri Pendidikan Nasional No. 58 tahun 2009.

Rachmawati, Y \& Kurniati, E. (2010). Strategi Perkembangan Kreativitas Pada Anak Usia Taman Kanak-kanak. Jakarta: Kencana Prenada Media Group.

Sukardi. (2003). Metodologi Penelitian Pendidikan Kompetensi dan Prakteknya. Jakarta: Bumi Aksara.

Yulianti, Dwi. (2010). Belajar Sambil Belajar Sains di Taman KanakKanak. Jakarta: PT Indeks. 